Aders, I., Smits, C., Brand, P., Dulmen, S. van. Does patient coaching make a difference in patient-physician communication during specialist consultations? A systematic review. Patient

\begin{tabular}{|l|l|}
$\begin{array}{l}\text { Postprint } \\
\text { Version }\end{array}$ & 1.0 \\
\hline Journal website & https://linkinghub.elsevier.com/retrieve/pii/S0738-3991(16)30582-1 \\
\hline Pubmed link & $\underline{\text { https://www.ncbi.nlm.nih.gov/pubmed/28089309 }}$ \\
\hline DOI & $10.1016 /$ j.pec.2016.12.029 \\
\hline
\end{tabular}

This is a NIVEL certified Post Print, more info at http://www.nivel.eu

\title{
Does patient coaching make a difference in patient-physician communication during specialist consultations? A systematic review
}

\author{
IRÈN ALDERS $^{A, B}$, CAROLIEN SMITS $^{\mathrm{B}}$, PAUl BRAND $^{\mathrm{C}, \mathrm{D}}$, SANDRA VAN DULMENA, $^{\mathrm{E}, \mathrm{F}}$ \\ a Dept. of Primary and Community Care, Radboud University Medical Centre, Nijmegen, the \\ Netherlands \\ b Research Group Innovation with Older Adults, Windesheim, University of Applied \\ Sciences, Zwolle, the Netherlands \\ c Amalia Children's Centre Isala, Zwolle, the Netherlands \\ d University Medical Centre Groningen, the Netherlands \\ e NIVEL (Netherlands institute for health services research), Utrecht, the Netherlands \\ f Faculty of Health Sciences, University College of Southeast Norway, Drammen, Norway
}

\begin{abstract}
Objective

To systematically review the literature on the effectiveness of a patient coach intervention on patient - physician communication in specialists consultations.

Methods

PubMed, Cochrane, PsycInfo, Cinahl and Embase were searched until November 2015. Included were papers describing interventions directed at adult outpatients in secondary care with a variety of somatic diseases. Outcomes had to be measured in communication effectivity from a patient's perspective.

Results

Seventeen publications met the inclusion criteria (involving 3787 patients), describing 13 unique interventions. Most interventions were single one-on-one sessions taking between 20 and 40 min before consultation. Research quality in ten studies was high. These studies showed significant improvement on immediate, intermediate and long term patient - physician communication.

Conclusion

We found limited evidence suggesting an improvement of patient - physician communication by having multiple patient coaching encounters during which questions are prepared and rehearsed and consultations are evaluated and reflected upon, sometimes supported by audio recording the consultation.

Practice implications

The results of this review contribute to the (re-)design of an effective model for patient coaching, a profile and training approach of patient coaches. Future
\end{abstract}


Aders, I., Smits, C., Brand, P., Dulmen, S. van. Does patient coaching make a difference in patient-physician communication during specialist consultations? A systematic review. Patient Education and Counseling: 2016

research should aim at determining which patients will benefit most from coaching interventions.

\section{INTRODUCTION}

Research shows that patients want to be heard and to be taken seriously in consultations with physicians [1]. Patients with a chronic illness are increasingly expected to self-manage their disease, which implies being involved in treatment decisions as well. In most cases, treatment is initiated by a medical specialist, therefore a patient's ability to communicate effectively during these consultations is essential [2], [3] and [4]. Patients need to be aware of and skilled to disclose relevant personal information about preferences, values and concerns [5]. Several factors reduce the likelihood that patients get the communicative approach they want and need during medical consultations, even though healthcare providers are doing their best to serve the patient's needs [6].

Barriers to communication have been reported in a systematic review on shared decision making [7]. Thirty three papers concerned studies in secondary care. Patients in these studies were diagnosed with various diseases, like cancer, cardiac diseases, diabetes, osteoporosis, hernia or asthma. Reported barriers related to how the healthcare system is organized and the interaction between patient and physician during consultation [7].

The complex hospital environment with full waiting rooms, difficult navigation through departments and clinic, dealing with many different healthcare professionals, and time constraints imposed by busy healthcare professionals, challenges communication during clinical consultations [8] and [9].

In the interactional context barriers relate to the power imbalance between patient and physician. This involves, from a patient's perspective, presumptions about their role and undervalued expertise in relation to the physician's knowledge [7]. Furthermore, the communication style of individual healthcare professionals may hinder effective communication with patients, for example by being hasty or by communicating in an excessively technical and instrumental way [8]. Patients also perceive several barriers within themselves, for example being overwhelmed by emotions, counterproductive values and beliefs [8], and lacking conversational skills or cognitive abilities, to be an active participant during healthcare visits [10]. The influence of barriers declines as patients become more experienced in their treatment trajectory. Van Bruinessen et al. identified a pattern of three states in patients communicating with healthcare professionals: 1) being overwhelmed and passive, 2) being pro-active and 3) being self-motivated, proficient and empowered. In line with the 'conscious competence learning' - model by Maslow, moving towards a next state in this trajectory might be facilitated by increasing patients' awareness on the role patients can play and the benefits of active participation [11], and additionally acquire the skills to communicate about their values, concerns and context in a participatory manner. Although most chronically ill patients move to subsequent states as time evolves after diagnosis, some patients remain in the first state of being unconsciously incompetent [8] during their treatment trajectory. To increase the number of patients that move from the first state to the second or even third, or accelerate this transition Van Bruinessen et al. suggested interventions should focus on creating awareness about the role patients can play during consultations and on training their communication skills [8]. Joseph-Williams et al. 
Aders, I., Smits, C., Brand, P., Dulmen, S. van. Does patient coaching make a difference in patient-physician communication during specialist consultations? A systematic review. Patient Education and Counseling: 2016

suggested to use alternative ways to prepare a patient for the shared decision making encounters: in addition to decision aids supporting the patient's ability to participate in the shared decision making process, focus should also be on how to handle the power imbalance between patient and physician [7].

Standardized communication and educational strategies to achieve patient empowerment are challenging, because patients' support needs are complex (influenced by health literacy level, social and cultural differences), can change over time and vary between contexts [12]. The identification in clinical practice of patients who will benefit most from coaching is challenging as well and requires further investigation.

Personal attention may be best suited to adapt to changing needs and circumstances. After all, human connection is fundamental in person centered patient care, and patients require human connection to feel respected and equal [13]. In a study among patients visiting medical specialists in Dutch hospitals, $16.6 \%$ of patients stated that they would appreciate a personal coach to help them prepare, execute, and evaluate medical consultations. Patients expressed the need for support to inform the provider about their preferred position in the process of medical decision-making, and help them to articulate their most important values and concerns at different stages during the treatment trajectory [14].

Previous reviews investigated such patient coaching interventions in different healthcare settings [15], [16], [17], [18], [19], [20], [21], [22] and [23]. The majority of these studies however, were limited to interventions provided before consultations [20] and [23], to patients with cancer [18], or directed only at practitioners [22]. The effects of personal, patient directed interventions for patients consulting a medical specialist, aiming to improve communication, and its effective components have not yet been systematically reviewed. This review therefore aims to increase understanding in these interventions and their effect on communication during consultation.

We performed a systematic review according to the PRISMA guidelines [24] to address the following research questions:

(1) Which patient coaching interventions have been developed and studied with respect to effectiveness on communication?

(2) How are these interventions provided (what elements are included, at what moment related to the consultation, how often and by whom)?

(3) Do coaching interventions significantly influence patient communication in specialist consultations?

Answers to these questions can be used to develop new or adapt existing patient coaching interventions.

\section{METHODS}

\subsection{Search strategy}

We conducted a systematic literature search in PubMed, Cochrane, PsycInfo, Cinahl and Embase until November 2015. The search strategy was developed by the first author (IA), with librarian support, primarily for PubMed (Appendix A) and adjusted accordingly for the other databases. 
Aders, I., Smits, C., Brand, P., Dulmen, S. van. Does patient coaching make a difference in patient-physician communication during specialist consultations? A systematic review. Patient Education and Counseling: 2016

The search was divided into three aspects to find relevant references on (1) patient coaching interventions (Intervention) to improve (2) patient-physician communication (Outcome) with medical specialists, in (3) secondary care (Setting). Studies had to be designed with a control condition.

Because 'patient coaching' is not a MeSH term in PubMed, we conducted a sensitive search to cover patient-directed personal support that aimed at enhancing patientspecialist communication during consultation. For this review we used a broad definition of coaching as used in education of Dutch nurses, and adjusted it to the context of a patient [25]. Patient coaching then has the following characteristics: 1) develops potential in a patient methodologically; 2) focuses on the patient and realization of his or her goals; 3 ) enhances learning and acting; 4) provides measurable results in attitude, knowledge and skills; 5) comprises dialogue on positive and negative aspects of the situation; 6) aims at improvement in consciousness and responsibility in a patient's healthcare and 7) is applied consciously in a restricted period of time. The goal of the patient coaching is determined by the patient, and the coach merely facilitates the process to reach it. No restrictions on timing of the intervention in the treatment trajectory were used. Outcomes had to be defined in communication effectivity from the patient's perspective during consultation, including patient participation, question asking behavior, stating values and concerns and expressing pReferences We did a broad search on adult outpatients consulting a medical specialist. No restrictions were made in kind of somatic disease, social economic status, education, ethnicity and (health) literacy levels.

Details of the search strategy are presented in Appendix A. Titles and abstracts of retrieved studies were checked by two independent reviewers against predefined inclusion criteria (Table 1). Studies not fulfilling one or more inclusion criteria were excluded. Disagreements were resolved by discussion.

\section{[TABLE 1]}

\subsection{Inclusion}

Studies were included if they investigated effects on communication in an empirical controlled study (parallel controlled: randomised controlled trial (RCT) or sequentially controlled: self-control or cross over) of personal support interventions given to an adult outpatient ( $\geq 18$ years of age) with no cognitive impairment. The intervention could have been provided groupwise or individually and had to be related to consulting a medical specialist. Communication support in curative trajectories may differ from support in palliative trajectories [26] and [27], therefore we limited our search to interventions in curative settings (Table 2).

[TABLE 2]

Interventions were excluded if they only focused on advocating a patient's interest by taking over instead of improving empowerment, translation, therapy or prevention.

\subsection{Study selection}

The search resulted in 12761 unique publications. Fig. 1 shows the selection process. The inclusion process was piloted on three random samples of 50 retrieved articles each by two researchers (IA and SvD). Differences were resolved by consensus, and 
Aders, I., Smits, C., Brand, P., Dulmen, S. van. Does patient coaching make a difference in patient-physician communication during specialist consultations? A systematic review. Patient Education and Counseling: 2016

the process resulted in the final list of in- and exclusion criteria and practical guidelines for selection (see).

\section{[FIGURE 1]}

Sixty-five articles were reviewed full text by IA and CS. In case of disagreement the other authors (SvD and PB) were consulted until agreement was reached. Forty eight references were excluded after reading full text, because they did not meet the inclusion-criteria after all. For example: it became clear the consultation was with a general practitioner instead of a medical specialist, or communication effectivity was not an outcome.

The few systematic reviews we found were checked for additional studies beyond our search, which resulted in two additional studies [28] and [29].

\subsection{Quality assessment}

Studies meeting the inclusion-criteria were assessed for methodological quality. This was completed by two reviewers (IA and SvD, PB or CS) using the Cochrane assessment tool (Appendix B) [30] and [31].

Studies were considered of high quality if six of the eleven criteria were scored as 'done' instead of 'unclear' or 'not done'. Disagreement was resolved by discussion.

\subsection{Data extraction}

Data were extracted by two independent reviewers using a self-made data extraction form, including study design, patient population, disease type, intervention (name, description, type, additional materials, frequency, timing, time period, control group), coach (background, training duration, training frequency, training methods), outcomes (primary outcome(s), secondary outcome(s), including used measurements), and study limitations.

Communication outcomes were qualified as 'immediate' if consultations were audiotaped and coded on communication aspects. Outcomes were qualified as 'intermediate' when measured directly after the consultation and as 'long term' measured after weeks or months. To investigate intermediate or long term effects patients were interviewed (face-to-face or by telephone) or asked to fill out questionnaires (validated and non-validated).

\section{RESULTS}

\subsection{Included studies on patient coaching interventions.}

Seventeen articles were included, describing thirteen unique interventions on a total of 3787 patients. Three interventions were investigated in multiple studies: Expanding Patient Involvement in Care (EPIC) [32], [33] and [34], Tailored Education and Counselling (TEC) [35] and [36] and Consultation Planning (CP) [37] and [38].

Research quality in ten studies was high. Control conditions varied in the included studies. Most studies compared a single intervention to a control group [28], [29], [32], [33], [39], [40], [41] and [42], some compared two interventions to a control group [35], [43], [44] and [45], one study compared three interventions to a control group [34] and some had a pre-post design [28], [32], [38], [40], [46] and [47]. 
Aders, I., Smits, C., Brand, P., Dulmen, S. van. Does patient coaching make a difference in patient-physician communication during specialist consultations? A systematic review. Patient Education and Counseling: 2016

\subsection{Patient characteristics}

Details on clinical and demographic characteristics of patients in the included studies are given in Table 3. Although most studies $(n=11)$ involved patients with cancer, others involved a range of other chronic diseases.

\section{[TABLE 3]}

\subsection{Descriptions of the interventions}

Most coaching interventions involved a single individual session taking between 20 and $40 \mathrm{~min}$ before consultation, given in the waiting room or a separate room in the hospital. Individual interventions were sometimes offered multiple times (2-5 times) [29], [33], [42], [43] and [45] or were combinations of individual session, telephone, mail or a group meeting [29] and [42].

All group workshops involved multiple meetings of varying duration [39], [40], [42] and [46].

Patients were coached on a variety of subjects, related to question asking (identifying, information recall, communication skills), decision making, conversation control (agenda setting, negotiation skills) and challenged to act by rehearsal and role-playing. In Mishel et al. [45] the patient support person (partner, relative, or friend) was also approached in the intervention. Consultation Planning and Recording [38] was the only intervention in which the coach accompanied a patient during the medical consultation. In this study two different coach roles were investigated: the coach helped to structure and record the consultation, compared to a coach who just recorded the consultation and only spoke when asked to by the patient or physician (Table 4).

\section{[TABLE 4]}

In all but one intervention additional material was described, like a Question Prompt List (or similar question support instrument), an audiotape of the consultation, an educational DVD, booklet, algorithm, flow/reminder chart, or combinations of these (Table 5).

\section{[TABLE 5]}

Coaching was provided by coaches of different backgrounds. They could be lay persons [35], [36], [39] and [46], healthcare professionals [29], [32], [42] and [45], researchers [28], [33], [34], [38], [40] and [48], social workers, or other professionals with a psychosocial education [41] and [43]. Two studies on Tailored Education and Counselling (TEC) [35] and [36] included a short description of the training of the coaches, e.g. 3-80 h of training and reinforcement over a period of 3-6 months. Fidelity of the intervention was tested in three studies [35], [43] and [45].

\subsection{EFFECTS ON COMMUNICATION (RQ3)}

Studies were too heterogeneous to pool the data, therefore results of the studies will be discussed separately, starting with the studies of high methodological quality.

Various outcome measures on communication were used: question asking behavior; perceived problems or barriers in communication; discussion with physician; active role in decision making; intensity of conversation (for example: the proportion of personal involvement by both physician and patient behavior in affect and opinion 
Aders, I., Smits, C., Brand, P., Dulmen, S. van. Does patient coaching make a difference in patient-physician communication during specialist consultations? A systematic review. Patient Education and Counseling: 2016

sharing) and involvement in conversation (for example: patient's conversational acts per minute); conversation controlling behaviors (questions, interruptions and directions by patients); obtaining information; self-efficacy (in asking questions); number of questions asked; change in satisfaction; or agreement with decision. All ten studies of high methodological quality showed significant effects on immediate, intermediate or long term communication outcomes. Coaches in these studies had a variety of backgrounds from lay educators to trained professionals or nurses. Three studies investigated group workshops that were in some interventions combined with phone calls and mail. Workshops were all given multiple times (3-6 times).

\subsubsection{Immediate effects}

Four of the ten studies of high methodological quality showed that patients assumed a significantly more active role in treatment decision making during consultation with medical specialists when they had seen a patient coach prior to the consultation: by actually participating [28], they were more involved in the conversation [32], improved their conversational controlling behavior [33] and showed more painspecific active participation [36]. These were all individual coaching sessions, three of which were given once and one twice [33].

\subsubsection{Intermediate effects}

In the study of Mishel (2009) patients reported a significant improvement in patientprovider communication measured directly after specialist consultation [45]. This intervention consisted of four phone calls to patient alone by a specially trained nurse, or to patient and primary support person both, separately, by the same nurse, over a period of 7-10 days. There was no significant difference in intermediate effect whether the primary support person was approached or not [45].

Two interventions (individual, once given, 20-30 min, just before specialist consultation) significantly improved elicitation of the number of factual statements from the physician [32] or led to a significant decline in perceived barriers about pain [41] in comparison to the control group.

\subsubsection{Long term effects}

Long term effects were measured after one to twelve months in half of the high quality studies. Significant improvements were found in patient-physician communication [39], [42] and [45], discussion with physicians [43] and sharing of information by patients [29] and [45]. Participation in planning treatment significantly improved in the intervention which was directed both at patients and patient support persons. It was not explained why the inclusion of a patient support person in the intervention made a difference specifically in this outcome [45]. In the low methodological quality studies, two out of seven studies showed no significant effects [40] and [44].

Sepucha (2000 and 2002) showed immediate significant improvement in decision quality and intersubjective agreement between physician and patient [38], and a reduction in communication barriers [37]. Kidd (2004) showed a significant intermediate improvement in self-efficacy in question asking especially when it was a familiar doctor [34]. Communication self-efficacy improved significantly in Kravitz (2011), but those groups already differed at baseline. Ory (2013) found long term improved communication with physician sustaining up to twelve months [46]. 
Aders, I., Smits, C., Brand, P., Dulmen, S. van. Does patient coaching make a difference in patient-physician communication during specialist consultations? A systematic review. Patient Education and Counseling: 2016

\section{DISCUSSION AND CONCLUSION}

\subsection{Discussion}

This systematic review of studies on personal coaching interventions directed at improving patient-physician communication during specialist consultations showed that personal support is able to improve patient communication (1) immediately, i.e. during consultation, (2) intermediately, i.e. as perceived after consultation, and (3) at the long term follow-up, i.e. the effect was sustainable. Even though these outcomes are promising, it was not possible to be conclusive about the effectiveness of the interventions or specific elements, because of the heterogeneity of the studies, the outcome measures and the intervention designs.

Comparable conclusions were drawn in the systematic reviews [15], [16], [17], [18], [19], [20], [21], [22] and [23] that included patient coaching interventions in specialist consultations in different patient groups (cancer [18], multiple sclerosis [17], chronic heart failure [15] and miscellaneous other groups). In addition to the reasons for inconclusiveness of the results described earlier, these reviews highlighted the complexity of the interventions and the low quality of the evidence [16] and [17]. The difficulty of determining the right outcome measures [15] and [18] (for example quality of questions, reduction of anxiety [20]) for effective communication to indicate increased patient participation [21] has been recognized before. These reviews were also inconclusive about whom to direct, though Legaré (2014) concluded that an intervention directed at both patient and healthcare professional showed to be more promising [16]. It was recommended to underpin interventions with a theoretical framework [22], design interventions that can be integrated into practice [19] and identify specific patient groups to target the intervention to [21].

All interventions included in our review were complex. Complex interventions comprise a number of interacting components, depend largely on the fidelity of coaches, are influenced by the context in which they are given and differ often in the number and variability of outcomes. These factors make the working mechanisms difficult to evaluate [49]. Evaluation of effective components in an RCT would strengthen the evidence if it were possible to disentangle components and study them as separate variables. Valuable information on what seems to be effective might be collected from qualitative studies and nonrandomized studies instead.

The outcomes in the included studies were related to the goal of the interventions, which primarily aimed to increase self-management skills, self-efficacy, active participation in decision making or interaction with physician, provision of knowledge on the disease and, only in some studies in particular, improve communication skills. Different pathways to reach these goals were chosen, resulting in a variety of intervention designs.

Different definitions for patient coaching are used in literature. As there is no uniform definition of coaching, we adopted a definition of coaching that is used in education of Dutch nurses [25] and adjusted it to the context of a patient. Main characteristics are that (1) the goal is provided by the patient and (2) the coach works methodologically (3) within a restricted period of time.

Since the coach is a crucial intervention component, information on background and training is essential, as well as the fidelity to the coaching method. However, information on the training of coaches (like training duration, training frequency and 
Aders, I., Smits, C., Brand, P., Dulmen, S. van. Does patient coaching make a difference in patient-physician communication during specialist consultations? A systematic review. Patient Education and Counseling: 2016

training methods) was limited. The fidelity to the coaching method was assessed in three studies [35], [43] and [45].

Comprehensive assessment of patients' needs, values and preferences as a foundation for person centered care (PCC), for example in Chronic Heart Failure, is beneficial in the tailoring of care [15]. A 'one size fits all' approach is not likely to meet patients' preferences as well as during the various stages of their trajectory for participation, because this varies among patients [50]. Personal attention and support by a patient coach might fit in well in this concept.

The frequency within which the intervention is provided also seems to have a positive influence on communication outcomes. Multiple encounters provide the opportunity to evaluate and reflect on behavior, thus creating a learning cycle in concordance with the 'conscious competence learning'- model by Maslow, other adult learning theories [51] and behavioral change theories [52] and [53]. This effect might be the largest when coach-patient encounters are at least provided before and after specialist consultations. Factual evaluation and reflection of patient's behavior and communication might also be facilitated hen the coach attends the consultation with the patient [38]. Because most interventions were given only once before a consultation, the effectiveness of multiple encounters is not yet substantiated. Workshops were all given multiple times, but are challenging preparation and evaluation of the consultation and reflection on actual behavior during consultation, because they were not directly related to the consultation.

Awareness on important issues for patients to address during specialist consultations like values, concerns and questions, can be developed by preparation (e.g. using a question prompt sheet on common issues), though it is hard to cover all relevant issues. Actual communication on these issues can be facilitated by rehearsal with a coach, which was provided in three studies of high methodological quality [29], [32] and [36].

Besides personal contact with a coach, another element that might be effective is audio recording, as used in some interventions [29] and [38]. Audio recordings are highly valued by patients in some situations and a majority benefits from listening to the recordings of their consultations [54]. Audio recordings improve recall and satisfaction in specialist consultations, but are more valued by younger patients [55]. Whether audiotapes are beneficial depends on a patient's preferences. In the article of Sepucha et al. (2000) [38] the coach arranged audiotaping the consultation. This facilitated the use of an audiotape, because patients are reluctant to do so themselves or use them covertly [56].

The complexity of the interventions in our review is further substantiated by the different contexts in which they were provided. Not only did they differ in number of participants (i.e. provided individually or in a group), but also in different places which may have different impacts on anxiety and learning ability (e.g. in hospital [28], [32], [33], [34], [35], [36], [37], [38], [41], [44] and [45] - in waiting room, unspecified space or private space, workshop location [39] and [40], at home [29], [42], [43] and [46]).

Only a few patient coaching interventions have been investigated in multiple studies and different contexts, which might be helpful to get a better understanding on effective elements.

Due to the factors mentioned above a conclusive evaluation on effective elements is not possible. 
Aders, I., Smits, C., Brand, P., Dulmen, S. van. Does patient coaching make a difference in patient-physician communication during specialist consultations? A systematic review. Patient Education and Counseling: 2016

Professional communication skills tend to decline over time unless they are regularly recalled and practiced [57] and [58]. Empowered ('coached') patients might challenge physicians with every consultation to practice trained skills [59]. Although communication skills training is mandatory for most healthcare professionals, many health care professionals encounter difficulties practising these skills in the consultation room [57], [60] and [61]. In some studies the effect of a patient coach intervention on physician behavior (immediate) was examined as well. As a result of patients actively communicating about their pain, physicians communicated more informatively [36]. Also Greenfield's study [32] showed a significant improvement in eliciting the number of factual statements from the physician.

The studies we reviewed included patients with different chronic diseases. The effect of coaching on patient communication did not appear to be disease-specific. There was no evidence in the studies in our review that the beneficial effects of coaching was mediated by demographic, socio-economic or health literacy status variables. It is recommended that healthcare professionals should tailor their information and support to the health literacy skills and personal context of their patients [62]. Since clinicians tend to overestimate the health literacy of their patients [63], it is essential that the information a patient provides during consultation is accurate, reflecting their actual issues. Patient coaching showed a significant long-term improvement of health literacy [42] and [46]. Further investigation should aim at exploring which patients will benefit most from a patient coach and whether health literacy is one of the characteristics of these patients.

The strengths of this review are its rigor, as expressed in the use of the PRISMA guidelines to design the search terms and the evaluation of the methodological quality of the included trials, using the Cochrane assessment tool. This is also the first review focusing solely on the effect of a personal coach intervention on patient - physician communication, aiming to further understand in the relationship between this intervention and its effects. We conducted a broad, sensitive search using the search terms "communication" and "relationship" to capture the main components of patient participation.

This review has some limitations. Patient coaching was not a Mesh term in PubMed and has various definitions. Despite our broad search strategy we might have missed some articles on relevant interventions. Bias may have been introduced as the second reviewer (SvD) only screened a small part of the titles and abstracts. Only English abstracts and studies in western countries were included; no information was gathered on possible patient coach interventions in other regions.

Many interventions aim to improve patients' self-efficacy in managing their disease or health, such as patient activation and patient navigation. We only included studies that used communication or relation with a physician as outcome. The small number of included studies and the use of combined outcome measures on communication call for caution in formulating firm conclusions on the results of this review. On the other hand it highlights the gap of knowledge on the effect of patient coaching on communication with medical specialists.

Self-reported intermediate and long term communication outcomes are less reliable in measuring outcomes than observing the consultation.

Many questions still remain unanswered. What are effective elements of a patient coach intervention? How important is timing of coaching in relation to consultation? What is the cost-effectiveness of a personal coach compared to non-personal 
Aders, I., Smits, C., Brand, P., Dulmen, S. van. Does patient coaching make a difference in patient-physician communication during specialist consultations? A systematic review. Patient Education and Counseling: 2016

support? What is the influence on the care process (knowledge necessary to inform the clinical practice) to facilitate implementation of a patient coach? What are the requirements for the provider of personal support (the 'coach')? Answers to these questions might help to (re)develop an effective patient coach intervention and the adoption and implementation of personal support for patients by the healthcare system in communicating with medical specialists on the subjects that matter to them.

\subsection{Conclusion}

Patient coaching seems a promising intervention to support patients in specialist consultations. The relative paucity of studies on the subject and the complexity of the patient coaching interventions limit the conclusions which can be drawn from this review.

Patients appear to benefit most from multiple coaching encounters, reparation and rehearsal of questions, evaluation and reflection on behavior and actions, comprising individual coach-patient encounters and support in audio recording the consultation to establish sustaining improvement in patient - physician communication in specialist consultations.

\subsection{PRACTICE IMPLICATIONS}

The results of this review contribute to the (re-)design of an effective model for patient coaching, a profile and training approach of patient coaches. Future research should aim at determining which patients will benefit most from coaching interventions.

\section{CONFLICT OF INTEREST}

The authors declare no conflict of interest.

\section{FUNDING}

This research did not receive any specific grant from funding agencies in the public, commercial, or not-for-profit sectors.

\section{ACKNOWLEDGEMENTS}

We thank Harm-Wouter Snippe for the provision of a very useful digital tool to select references for inclusion based on title and abstract; Elmie Peters and Linda Schoonmade for their support in creating the proper search strategy; Fuus van der Graaff, Nicolien Kromme and Antoine Bakx for their advice on previous versions of this paper.

\section{[APPENDIX A][APPENDIX B]}

\section{Methodological quality:}

High quality: the study adequately fulfilled $50 \%$ or more of the validity criteria (6 or more out of 11 criteria). Low quality: the study fulfilled less than $50 \%$ of the validity criteria ( $<6$ out of 11 criteria) 
Aders, I., Smits, C., Brand, P., Dulmen, S. van. Does patient coaching make a difference in patient-physician communication during specialist consultations? A systematic review. Patient

\section{OPERATIONALISATION OF THE Validity CRITERIA LIST}

1) Was the method of randomisation adequate, e.g.at patient level? Examples of adequate methods are computer generated random number table and use of sealed opaque envelopes. Score yes if the above is the case. Score no if a transparent system is used and score don't know when the method of randomization is not described in the article.

2) Was the assignment generated by an independent person not responsible for determining the eligibility of the patients? This person has no information about the persons included in the study and has no influence on the assignment sequence or on the decision about the eligibility of the patients. Score yes when the assignment has been taken place by an independent person. Score no if the above is not the case and score don't know if no information is given about who generated the assignment.

3) Are important prognostic indicators assessed at baseline? Are there no substantial differences between the intervention group and the control group (for example regarding age, sex, type of cancer, duration of the disease, stadium of the disease, cognitive status and type of treatment)? Score yes if the above is the case and score no if there are differences regarding the prognostic indicators at baseline that could undermine post intervention differences. Score also no if no testing has been done to check if there were actual differences (a table with prognostic indicators without explanation is not enough). Score don't know when no information had been given about prognostic indicators.

4) Was the patient blinded to the intervention? The reviewer determines if enough information is given in order to score a 'yes'. Score don't know if no information is given.

5) Was the care provider blinded to the intervention? The reviewer determines if enough information is given in order to score a 'yes'. Score don't know if no information is given.

6) Was the outcome assessor blinded to the intervention? The reviewer determines if enough information is given in order to score a 'yes'. Score don't know if no information is given.

7) Were co-interventions avoided in the design or were they similar between the intervention groups and control group? Score yes if the above is the case. Score no if there were cointerventions, not similar for the different groups. Score also no when no information has been given about co-interventions (so, not tested is also no). Note. This criterion cannot be decisive in determining low quality of an article.

8) Was the compliance rate among patients evaluated (e.g. did they view the received video or read the written material)? Score yes if the percentage of patients that used the intervention is above 70\% in all groups. Score no if this percentage is below $70 \%$ and score don't know if no information about compliance has been given.

9) Is the number of patients described (and reasons given) that were included in the study but did not complete the intervention or were excluded from analysis? Is this percentage of withdrawals or drop-outs acceptable? Score yes if there is information from 80 to $100 \%$ of the randomised patients about the outcome assessment of recall. Score no if there is information from less than $80 \%$ of the randomised patients and score don't know if no information about withdrawals or drop-outs has been given.

10) Was the timing of the outcome assessment in all groups similar? Score yes if the above is the case (score also yes if a range is described, provided that this range does not have a large spread, for example more than three months). Score no if the timing of outcome assessment was not similar for all groups and score don't know if no information about the timing was given. 
Aders, I., Smits, C., Brand, P., Dulmen, S. van. Does patient coaching make a difference in patient-physician communication during specialist consultations? A systematic review. Patient

\section{OPERATIONALISATION OF THE Validity CRITERIA LIST}

11) Was all available data included for analysis (intention to treat)? This means that all randomised patients were analysed in the group they were assigned to regardless of noncompliance and co-interventions. Score yes if the above is the case, score no when the analysis did not include an intention to treat analysis. Score don't know if no information about intention to treat is given.

\section{REFERENCES}

[1] M.A. Mazzi, M. Rimondini, M. Deveugele, C. Zimmermann, F. Moretti, L. van Vliet, et al. What do people appreciate in physicians' communication: an international study with focus groups using videotaped medical consultations Health Expect., 18 (2015), pp. 1215-1226

[2]R.L. Kruse, J.E. Olsberg, C.L. Shigaki, D.R. Parker Oliver, M.J. Vetter-Smith, T.M. Day, et al. Communication during patient-provider encounters regarding diabetes self-management Fam. Med., 45 (2013), pp. 475-483

[3] S.C. Chan, C.C. Chan, A.M. Siu, P.K. Poon A conceptual model of patient-professional communication as a self-management skill: a latent growth change modeling Disabil Health J., 8 (2015), pp. 602-610

[4] T. Jowsey, J. Gillespie, C. Aspin Effective communication is crucial to self-management: the experiences of immigrants to Australia living with diabetes Chronic Illn., 7 (2011), pp. $6-19$

[5] M.A. Mazzi, J. Bensing, M. Rimondini, I. Fletcher, L. van Vliet, C. Zimmermann, et al. How do lay people assess the quality of physicians' communicative responses to patients' emotional cues and concerns? An international multicentre study based on videotaped medical consultations Patient Educ. Couns., 90 (2013), pp. 347-353

[6] J. Bensing, D.S. van, K. Tates Communication in context: new directions in communication research Patient Educ. Couns., 50 (2003), pp. 27-32

[7] N. Joseph-Williams, G. Elwyn, A. Edwards Knowledge is not power for patients: a systematic review and thematic synthesis of patient-reported barriers and facilitators to shared decision making Patient Educ. Couns., 94 (2014), pp. 291-309

[8]I.R. van Bruinessen, E.M. van Weel-Baumgarten, H. Gouw, J.M. Zijlstra, A. Albada, S. van Dulmen Barriers and facilitators to effective communication experienced by patients with malignant lymphoma at all stages after diagnosis Psychooncology, 22 (2013), pp. 28072814

[9] D. Feldman-Stewart, M.D. Brundage, C. Tishelman, S.C. Team A conceptual framework for patient-professional communication: an application to the cancer context Psychooncology, 14 (2005), pp. 801-809 discussion 10-1

[10] I. Henselmans, M. Jacobs, M.I. van Berge Henegouwen, H.C.J.M. de Haes, M.A.G. Sprangers, E.M.A. Smets Postoperative information needs and communication barriers of esophageal cancer patients Patient Educ. Couns., 88 (2012), pp. 138-146

[11] A. Robinson, R. Thomson Variability in patient preferences for participating in medical decision making: implication for the use of decision support tools Qual. Health Care, 10 (Suppl. 1) (2001), pp. i34-8

[12] S.E. Thorne, B.L. Paterson Health care professional support for self-care management in chronic illness: insights from diabetes research Patient Educ. Couns., 42 (2001), pp. 8190

[13] K. Thorarinsdottir, K. Kristjansson Patients' perspectives on person-centred participation in healthcare: a framework analysis Nurs. Ethics, 21 (2014), pp. 129-147

[14] I. Henselmans, M. Heijmans, J. Rademakers, S. van Dulmen Participation of chronic patients in medical consultations: patients' perceived efficacy, barriers and interest in support Health Expect., 18 (2015), pp. 2375-2388

[15] P.M. Kane, F.E.M. Murtagh, K. Ryan, N.G. Mahon, B. McAdam, R. McQuillan, et al. The gap between policy and practice: a systematic review of patient-centred care interventions in chronic heart failure Heart Fail. Rev., 20 (2015), pp. 673-687 
Aders, I., Smits, C., Brand, P., Dulmen, S. van. Does patient coaching make a difference in patient-physician communication during specialist consultations? A systematic review. Patient Education and Counseling: 2016

[16] F. Legare, D. Stacey, S. Turcotte, M.J. Cossi, J. Kryworuchko, I.D. Graham, et al. Interventions for improving the adoption of shared decision making by healthcare professionals Cochrane Database Syst. Rev., 9 (2014), p. CD006732

[17] S. Kopke, A. Solari, F. Khan, C. Heesen, A. Giordano Information provision for people with multiple sclerosis Cochrane Database Syst. Rev., 4 (2014), p. CD008757

[18] I. Henselmans, H. De Haes, E.M.A. Smets Enhancing patient participation in oncology consultations: a best evidence synthesis of patient-targeted interventions Psychooncology, 22 (2013), pp. 134-135

[19] J.K. Rao, L.A. Anderson, T.S. Inui, R.M. Frankel Communication interventions make a difference in conversations between physicians and patients: a systematic review of the evidence (Structured abstract) Med. Care, 45 (2007), pp. 340-349

[20] P. Kinnersley, A. Edwards, K. Hood, R. Ryan, H. Prout, N. Cadbury, et al. Interventions before consultations to help patients address their information needs by encouraging question asking: systematic review BMJ, 337 (2008), p. a485

[21] J. Harrington, L.M. Noble, S.P. Newman Improving patients' communication with doctors: a systematic review of intervention studies Patient Educ. Couns., 52 (2004), pp. 7-16

[22] S.J. Griffin, A.L. Kinmonth, M.W. Veltman, S. Gillard, J. Grant, M. Stewart Effect on health-related outcomes of interventions to alter the interaction between patients and practitioners: a systematic review of trials Ann. Fam. Med., 2 (2004), pp. 595-608

[23] D.M. Post, D.J. Cegala, W.F. Miser The other half of the whole: teaching patients to communicate with physicians Fam. Med., 34 (2002), pp. 344-352

[24] A. Liberati, D.G. Altman, J. Tetzlaff, C. Mulrow, P.C. Gotzsche, J.P. loannidis, et al. The PRISMA statement for reporting systematic reviews and meta-analyses of studies that evaluate health care interventions: explanation and elaboration PLoS Med., 6 (2009), p. e1000100

[25] Van Beek MT, I. leren coachen. Leren Coachen. 6th, revised edition ed. Soest: Uitgeverij Boom/Nelissen; 2014. p. 20.

[26] H. Bergenholtz, L. Jarlbaek, B. Holge-Hazelton The culture of general palliative nursing care in medical departments: an ethnographic study Int. J. Palliat. Nurs., 21 (2015), pp. 193-201

[27] C. Gardiner, C. Ingleton, M. Gott, T. Ryan Exploring the transition from curative care to palliative care: a systematic review of the literature BMJ Supportive Palliat. Care., 5 (2015), pp. 335-342

[28] B.J. Davison, L.F. Degner Empowerment of men newly diagnosed with prostate cancer Cancer Nurs., 20 (1997), pp. 187-196

[29] D. Wilkie, D. Berry, K. Cain, H.Y. Huang, J. Mekwa, F. Lewis, et al. Effects of coaching patients with lung cancer to report cancer pain West. J. Nurs. Res., 32 (2010), pp. 23-46

[30] Higgins J, Altman DG. Cochrane Handbook for Systematic Reviews of Interventions. In: Higgins JPT ADe, editor. 5.0.1 ed: The Cochrane Collaboration, 2008.; 2008. p.

Home > Part 2: General methods for Cochrane reviews $>8$ Assessing risk of bias in included studies $>.5$ The Cochrane Collaboration's tool for assessing risk of bias $>$ Table 8.5. d: Criteria for judging risk of bias in the 'Risk of bias' assessment tool.

[31] M. van Tulder, A. Furlan, C. Bombardier, L. Bouter Editorial Board of the Cochrane Collaboration Back Review G: Updated method guidelines for systematic reviews in the cochrane collaboration back review group Spine (Phila Pa 1976)., 28 (2003), pp. 12901299

[32] S. Greenfield, S. Kaplan, J.E. Ware Expanding patient involvement in care: effects on patient outcomes Ann. Intern. Med., 102 (1985), pp. 520-528

[33] S. Greenfield, S.H. Kaplan, J.E. Ware, E.M. Yano, H.J. Frank Patients' participation in medical care: effects on blood sugar control and quality of life in diabetes J. Gen. Intern. Med., 3 (1988), pp. 448-457

[34] J. Kidd, T.M. Marteau, S. Robinson, O.C. Ukoumunne, C. Tydeman Promoting patient participation in consultations: a randomised controlled trial to evaluate the effectiveness of three patient-focused interventions Patient Educ. Couns., 52 (2004), pp. 107-112

[35] R.L. Kravitz, D.J. Tancredi, T. Grennan, D. Kalauokalani, J. Street, C.K. Slee, et al. Cancer Health Empowerment for Living without Pain (Ca-HELP): Effects of a tailored 
Aders, I., Smits, C., Brand, P., Dulmen, S. van. Does patient coaching make a difference in patient-physician communication during specialist consultations? A systematic review. Patient Education and Counseling: 2016

education and coaching intervention on pain and impairment Pain, 152 (2011), pp. 15721582

[36] R.L. Street, C. Slee, D.K. Kalauokalani, D.E. Dean, D.J. Tancredi, R.L. Kravitz Improving physician-patient communication about cancer pain with a tailored educationcoaching intervention Patient Educ. Couns., 80 (2010), pp. 42-47

[37] K.R. Sepucha, J.K. Belkora, S. Mutchnick, L.J. Esserman Consultation planning to help breast cancer patients prepare for medical consultations: effecton communication and satisfaction for patients and physicians J. Clin. Oncol., 20 (2002), pp. 2695-2700

[38] K.R. Sepucha, J.K. Belkora, D. Tripathy, L.J. Esserman Building bridges between physicians and patients: results of a pilot study examining new tools for collaborative decision making in breast cancer J. Clin. Oncol., 18 (2000), pp. 1230-1238

[39] J.H. Barlow, A.P. Turner, C.C. Wright A randomized controlled study of the Arthritis SelfManagement Programme in the UK Health Educ. Res., 15 (2000), pp. 665-680

[40] J.R. Bloom, S.L. Stewart, C.N. D'Onofrio, J. Luce, P.J. Banks Addressing the needs of young breast cancer survivors at the 5 year milestone: can a short-term, low intensity intervention produce change? J. Cancer Survivorship: Res. Pract., 2 (2008), pp. 190-204

[41] M.Y. Smith, K.N. DuHamel, J. Egert, G. Winkel Impact of a brief intervention on patient communication and barriers to pain management: results from a randomized controlled trial Patient Educ. Couns., 81 (2010), pp. 79-86

[42] G. Van Servellen, A. Nyamathi, F. Carpio, D. Pearce, L. Garcia-Teague, G. Herrera, et al. Effects of a treatment adherence enhancement program on health literacy, patientprovider relationships, and adherence to HAART among low-income HIV-positive Spanishspeaking Latinos Aids Patient Care STDS, 19 (2005), pp. 745-759

[43] L.E. Boulware, F. Hill-Briggs, E.S. Kraus, J.K. Melancon, B. Falcone, P.L. Ephraim, et al. Effectiveness of educational and social worker interventions to activate patients' discussion and pursuit of preemptive living donor kidney transplantation: a randomized controlled trial Am. J. Kidney Dis., 61 (2013), pp. 476-486

[44] R. Brown, P.N. Butow, M.J. Boyer, M.H.N. Tattersall Promoting patient participation in the cancer consultation: evaluation of a prompt sheet and coaching in question-asking $\mathrm{Br}$. J. Cancer, 80 (1999), pp. 242-248

[45] M.H. Mishel, B.B. Germino, L. Lin, R.S. Pruthi, E.M. Wallen, J. Crandell, et al. Managing uncertainty about treatment decision making in early stage prostate cancer: a randomized clinical trial Patient Educ. Couns., 77 (2009), pp. 349-359

[46] M.G. Ory, S. Ahn, L. Jiang, M.L. Smith, P.L. Ritter, N. Whitelaw, et al. Successes of a national study of the chronic disease self-management program: meeting the triple aim of health care reform Med. Care, 51 (2013), pp. 992-998

[47] K.R. Sepucha, I. Scholl Measuring shared decision making: a review of constructs, measures, and opportunities for cardiovascular care Circ. Cardiovasc. Qual. Outcomes, 7 (2014), pp. 620-626

[48] J.B. Brown, M. Boles, J.P. Mullooly, W. Levinson Effect of clinician communication skills training on patient satisfaction A randomized, controlled trial Ann. Intern. Med., 131 (1999), pp. 822-829

[49] P. Craig, P. Dieppe, S. Macintyre, S. Michie, I. Nazareth, M. Petticrew Developing and evaluating complex interventions: the new Medical Research Council guidance Int. J. Nurs. Stud., 50 (2013), pp. 587-592

[50] L. Brom, W. Hopmans, H.R. Pasman, D.R. Timmermans, G.A. Widdershoven, B.D. Onwuteaka-Philipsen Congruence between patients' preferred and perceived participation in medical decision-making: a review of the literature BMC Med. Inform. Decis. Mak., 14 (2014), p. 25

[51] M. Knowles Theories of Teaching. The Adult Learner: A Neglected Species Gulf Publishing Company, Houston (1973), pp. 50-53 (P.O. Box 2608, TX77001)

[52] S.C. Hayes, J.B. Luoma, F.W. Bond, A. Masuda, J. Lillis Acceptance and commitment therapy: model, processes and outcomes Behav. Res. Ther., 44 (2006), pp. 1-25

[53] Hayes Stephen C. S, Kirk D., Wilson.Kelly G. Acceptance en Commitment Therapie, veranderingen door mindfulness, het proces en de praktijk. 2e druk ed: Pearson; 2012.

[54] M. Tsulukidze, M.A. Durand, P.J. Barr, T. Mead, G. Elwyn Providing recording of clinical consultation to patients - a highly valued but underutilized intervention: a scoping review Patient Educ. Couns., 95 (2014), pp. 297-304 
Aders, I., Smits, C., Brand, P., Dulmen, S. van. Does patient coaching make a difference in patient-physician communication during specialist consultations? A systematic review. Patient Education and Counseling: 2016

[55] L.M.L. Ong, M.R.M. Visser, F.B. Lammes, J. Van der Velden, B.C. Kuenen, J.C.J.M. De Haes Effect of providing cancer patients with the audiotaped initial consultation on satisfaction, recall, and quality of life: a randomized, double-blind study J. Clin. Oncol., 18 (2000), pp. 3052-3060

[56] G. Elwyn, P.J. Barr, S.W. Grande Patients recording clinical encounters: a path to empowerment? Assessment by mixed methods BMJ Open, 5 (2015), p. e008566

[57] N.J. Perron, J. Sommer, M. Louis-Simonet, M. Nendaz Teaching communication skills: beyond wishful thinking Swiss Med. Wkly., 145 (2015)

[58] C.S. Schwalbe, H.Y. Oh, A. Zweben Sustaining motivational interviewing: a metaanalysis of training studies Addiction, 109 (2014), pp. 1287-1294

[59] B.A. Lown, W.D. Clark, J.L. Hanson Mutual influence in shared decision making: a collaborative study of patients and physicians Health Expect., 12 (2009), pp. 160-174

[60] N. Couet, S. Desroches, H. Robitaille, H. Vaillancourt, A. Leblanc, S. Turcotte, et al. Assessments of the extent to which health-care providers involve patients in decision making: a systematic review of studies using the OPTION instrument Health Expect., 18 (2015), pp. 542-561

[61] M.B. Laws, G.S. Rose, M.C. Beach, Y. Lee, W.S. Rogers, A.B. Velasco, et al. Patientprovider concordance with behavioral change goals drives measures of motivational interviewing consistency Patient Educ. Couns., 98 (2015), pp. 728-733

[62] M. Heijmans, G. Waverijn, J. Rademakers, V. van d, M. Rijken Functional, communicative and critical health literacy of chronic disease patients and their importance for self-management Patient Educ. Couns., 98 (2015), pp. 41-48

[63] M. Camargo, A. Federman, C. Horowitz Are clinicians overestimating the health literacy of their patients? J. Gen. Intern. Med., 28 (2013), p. S23

\section{TABLES}

Table 1. inclusion criteria for studies included in the systematic review.

\begin{tabular}{|l|}
\hline 1. Abstract available in English \\
\hline 2. Empirical study, experimental study \\
\hline 3. Adult patient $(>18$ years) \\
\hline \hline 4. Curative care \\
\hline 5. Consulting a medical specialist \\
\hline 6. Somatic complaint or disease (not mental) \\
\hline 7. Personal, individual or groupwise, intervention \\
\hline \hline 8. Goal: improving communication during specialist consultation \\
\hline 9. Outcome: patient-physician communication \\
\hline
\end{tabular}


Aders, I., Smits, C., Brand, P., Dulmen, S. van. Does patient coaching make a difference in patient-physician communication during specialist consultations? A systematic review. Patient

Education and Counseling: 2016

Table 2. studies, design and quality.

\begin{tabular}{|c|c|c|c|c|}
\hline author, year & design & involved hospitals & \begin{tabular}{|l} 
no. \\
Patients
\end{tabular} & $\begin{array}{l}\text { meth. } \\
\text { quality }\end{array}$ \\
\hline Barlow, 2000, & pragmatic RCT & $\begin{array}{l}\text { community based } \\
\text { intervention }\end{array}$ & 544 & high \\
\hline Bloom, 2008 & $\begin{array}{l}\text { RCT, pre post design } 0,6 \\
\text { months }\end{array}$ & & 404 & low \\
\hline Boulware 2013 & RCT & multi-site & 130 & high \\
\hline Brown, 1999 & RCT & 1 & 60 & low \\
\hline Davison, 1997 & RCT, pre post interviews & 1 & 60 & high \\
\hline $\begin{array}{l}\text { Greenfield, } \\
1985\end{array}$ & RCT, pre-post & $\mid 1$ & 45 & high \\
\hline $\begin{array}{l}\text { Greenfield, } \\
1988\end{array}$ & RCT & $\mid 2$ & 73 & high \\
\hline Kidd, 2004 & RCT & 1 & 202 & low \\
\hline Kravitz, 2011 & RCT & 4 & 258 & low \\
\hline Mishel, 2009 & $\operatorname{RCT}(3 \times 2)$ & 6 & 256 & high \\
\hline Ory, 2013 & $\begin{array}{l}\text { pre/post longitudinal } 0,6, \\
12 \text { months }\end{array}$ & 22 & 1170 & low \\
\hline Sepucha, 2000 & $\begin{array}{l}\text { sequentially controlled } \\
\text { trial }\end{array}$ & $\| 1$ & 24 & low \\
\hline Sepucha, 2002 & $\begin{array}{l}\text { sequentially controlled } \\
\text { trial }\end{array}$ & 2 & 94 & low \\
\hline Smith, 2010 & RCT & 5 & 89 & high \\
\hline Street, 2010 & RCT & 3 & 148 & high \\
\hline $\begin{array}{l}\text { Van Servellen, } \\
2005\end{array}$ & $\mathrm{RCT}$ & 2 & 81 & high \\
\hline Wilkie, 2010 & RCT, 4 weeks pre post & 11 & 151 & high \\
\hline
\end{tabular}


Aders, I., Smits, C., Brand, P., Dulmen, S. van. Does patient coaching make a difference in patient-physician communication during specialist consultations? A systematic review. Patient Education and Counseling: 2016

Fig. 1. flowchart inclusion procedure.
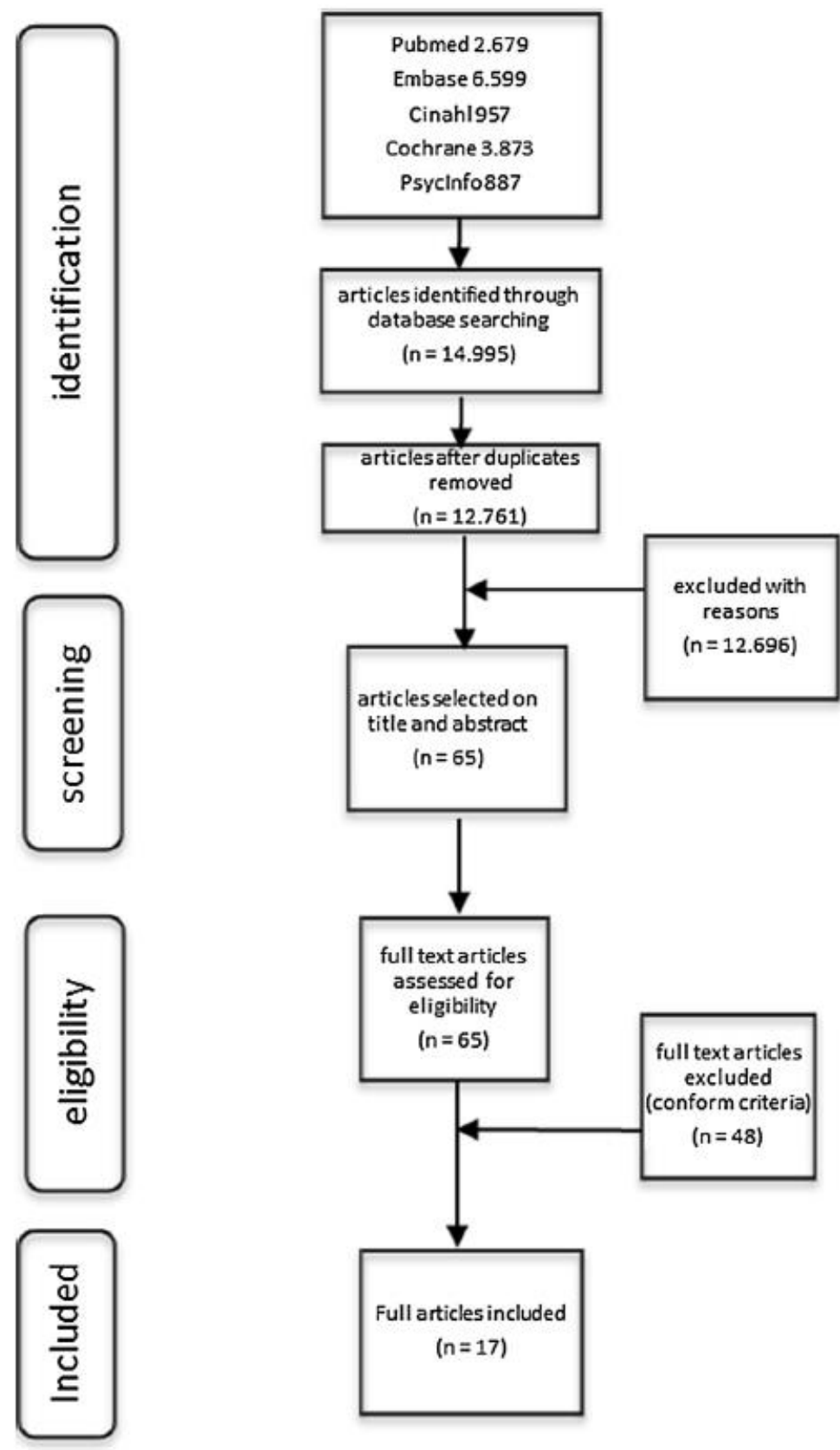
Aders, I., Smits, C., Brand, P., Dulmen, S. van. Does patient coaching make a difference in patient-physician communication during specialist consultations? A systematic review. Patient

Education and Counseling: 2016

Table 3. patient demographics, diseases.

\begin{tabular}{|c|c|c|c|c|c|c|}
\hline $\begin{array}{c}\text { author, } \\
\text { year }\end{array}$ & \begin{tabular}{|c|} 
country \\
(ies)
\end{tabular} & \begin{tabular}{|c||} 
no. \\
Patients
\end{tabular} & $\%$ men & age & disease & inclusion criteria \\
\hline $\begin{array}{l}\text { Barlow, } \\
2000,\end{array}$ & UK & 544 & $\sim 15 \%$ & \begin{tabular}{|l|} 
int. 57.3, \\
control \\
59.1 \\
\end{tabular} & $\begin{array}{l}\text { rheuma (OA } \\
\text { and RA) }\end{array}$ & $\begin{array}{l}>=18 \text { years; ability to complete } \\
\text { questionnaire; diagnosis } \\
\text { Arthritis. From GP }\end{array}$ \\
\hline $\begin{array}{l}\text { Bloom, } \\
2008\end{array}$ & USA & 404 & 0 & $23-50$ & cancer (breast) & $\begin{array}{l}\text { breast cancer, } 5 \text { year survivors; } \\
<=50 \text { years; cancer free; } \\
\text { contacts from earlier study }\end{array}$ \\
\hline $\begin{array}{l}\text { Boulware } \\
2013\end{array}$ & USA & 130 & $\sim 40 \%$ & $52-67$ & $\begin{array}{l}\text { Chronic kidney } \\
\text { disease (CKD) }\end{array}$ & $\begin{array}{l}\text { age } 18-70 ; \text { English speaking; } \\
\text { KDOQI stages } 3,4, \text { or } 5 \text { CKD } \\
\text { who were deemed to have } \\
\text { progressive; not yet initiated } \\
\text { dialysis therapy }\end{array}$ \\
\hline $\begin{array}{l}\text { Brown, } \\
1999\end{array}$ & Australia & 60 & $49 \%$ & $17-77$ & cancer, various & subsequent patients \\
\hline $\begin{array}{l}\text { Davison, } \\
1997\end{array}$ & Canada & 60 & $100 \%$ & $41-81$ & $\begin{array}{l}\text { cancer } \\
\text { (prostate) }\end{array}$ & $\begin{array}{l}\text { newly diagnosed prostate cancer } \\
(0-13 \text { weeks }) \\
\text { Having been told their } \\
\text { diagnosis, not having had their } \\
\text { initial treatment consultation; } \\
\text { able to read, speak and write } \\
\text { English, and no evidence of } \\
\text { mental confusion } \\
\end{array}$ \\
\hline $\begin{array}{l}\text { Greenfield, } \\
1985\end{array}$ & USA & 45 & $91 \%$ & 55 & peptic ulcer & $\begin{array}{l}\text { visit with clinic physician within } \\
6 \text { months; no record of psych } \\
\text { problems; Read English, less } \\
\text { than } 75 \text { years of age, peptic } \\
\text { ulcer }\end{array}$ \\
\hline $\begin{array}{l}\text { Greenfield, } \\
1988\end{array}$ & USA & 73 & $\begin{array}{l}\text { int: } \\
52 \%, \\
\text { control } \\
48 \%\end{array}$ & $\mid \begin{array}{l}\text { int: } 49.8, \\
\text { control } \\
49.5\end{array}$ & diabetes & $\begin{array}{l}\text { at least three previous clinic } \\
\text { visits, less than } 75 \text { years of age, } \\
\text { not blind, English speaking, not } \\
\text { on insulin pump, no other major } \\
\text { disease }\end{array}$ \\
\hline Kidd, 2004 & UK & 202 & 56 & $17-78$ & diabetes & $\begin{array}{l}\text { fluent English; attending } \\
\text { diabetic clinic Aug. '94- march } \\
\text { ‘95 }\end{array}$ \\
\hline $\begin{array}{l}\text { Kravitz, } \\
2011\end{array}$ & USA & 258 & 22.2 & mean 58 & $\begin{array}{l}\text { cancer } \\
\text { (various) }\end{array}$ & $\begin{array}{l}18-80 \text { years; cognitively intact; } \\
\text { English speaking; baseline waist } \\
\text { pain }>=4(1-10), \text { moderate } \\
\text { functional impairment due to } \\
\text { pain }\end{array}$ \\
\hline Mishel, & USA & 256 & 99 & mean 62 & cancer (prostate & at least ten days before treatment \\
\hline
\end{tabular}


Aders, I., Smits, C., Brand, P., Dulmen, S. van. Does patient coaching make a difference in patient-physician communication during specialist consultations? A systematic review. Patient

\begin{tabular}{|c|c|c|c|c|c|c|}
\hline $\begin{array}{c}\text { author, } \\
\text { year }\end{array}$ & \begin{tabular}{|c} 
country \\
(ies)
\end{tabular} & $\begin{array}{c}\text { no. } \\
\text { Patients }\end{array}$ & \% men & age & disease & inclusion criteria \\
\hline 2009 & & & & & 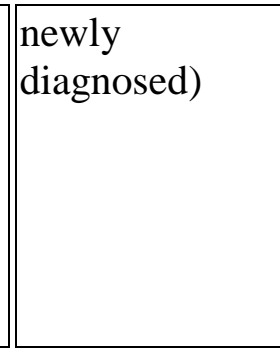 & $\begin{array}{l}\text { lonsult appointment; }<\mathrm{T} 2 \mathrm{~b}, \\
\text { Gleason }<10 ; \text { PSA }<20 ; \text { no } \\
\text { major cognitive impairment; } \\
\text { ability to read; access to phone; } \\
\text { no prior cancer history; PSP } \\
\text { (primary support person) willing } \\
\text { to participate }\end{array}$ \\
\hline Ory, 2013 & USA & 1170 & $18,3 \%$ & $19-80$ & \begin{tabular}{|l} 
chronic \\
disease: cancer, \\
COPD, \\
diabetes, \\
arthritis
\end{tabular} & $\begin{array}{l}\text { Min } 1 \text { self-reported chronic } \\
\text { disease } \\
\text { - Enrolling in CDSMP } \\
\text { workshop in English or Spanish } \\
\text { - Attending at least one of the } \\
\text { first } 2 \text { class sessions } \\
\text { - Not having taken CDSMP } \\
\text { classes before } \\
\text { - Completing a baseline } \\
\text { assessment } \\
\text { - Consenting to the study }\end{array}$ \\
\hline $\begin{array}{l}\text { Sepucha, } \\
2000\end{array}$ & USA & 24 & 0 & $\begin{array}{l}\text { int. } 48- \\
\text { control } \\
47\end{array}$ & cancer (breast) & $\begin{array}{l}\text { breast cancer, read and speak } \\
\text { English, consulting specialist } \\
\text { about treatment June } 1998- \\
\text { Nov. } 1998\end{array}$ \\
\hline $\begin{array}{l}\text { Sepucha, } \\
2002\end{array}$ & USA & 94 & 0 & $\begin{array}{l}\text { int. 53, } \\
\text { control } \\
52\end{array}$ & cancer (breast) & $\begin{array}{l}\text { breast cancer, read and speak } \\
\text { English, consulting specialist } \\
\text { about treatment, Oct. } 96-\text { Mrt. } \\
97\end{array}$ \\
\hline $\begin{array}{l}\text { Smith, } \\
2010\end{array}$ & USA & 89 & 0 & $\begin{array}{l}\text { int. } 52 \\
- \text { control } \\
49,8\end{array}$ & cancer (breast) & \begin{tabular}{|l} 
adult female 18 plus, confirmed \\
diagnosis of breast cancer, self- \\
reported presence of persistent \\
pain of at least moderate \\
intensity (score of 4 plus on \\
Brief Pain Inventory's worst \\
Pain Intensity item) over prior 2 \\
weeks \\
-absence of any gross cognitive \\
impairment, ability to \\
comprehend, speak and read \\
with basic fluency in either \\
English or Spanish \\
\end{tabular} \\
\hline $\begin{array}{l}\text { Street, } \\
2010\end{array}$ & USA & 148 & $\sim 20 \%$ & $\begin{array}{l}\text { int. } 59,8, \\
\text { control } \\
56,6\end{array}$ & \begin{tabular}{||l} 
Cancer (locally \\
advanced or \\
disseminated, \\
various)
\end{tabular} & \begin{tabular}{|l} 
(a) scheduled to see a \\
participating physician, (b) were \\
English-speaking and between \\
the age of 18 and $80,(c)$ had a \\
diagnosis of locally advanced or
\end{tabular} \\
\hline
\end{tabular}


Aders, I., Smits, C., Brand, P., Dulmen, S. van. Does patient coaching make a difference in patient-physician communication during specialist consultations? A systematic review. Patient

\begin{tabular}{|c|c|c|c|c|c|c|}
\hline $\begin{array}{c}\text { author, } \\
\text { year }\end{array}$ & $\begin{array}{c}\text { country } \\
\text { (ies) }\end{array}$ & $\begin{array}{c}\text { no. } \\
\text { Patients }\end{array}$ & $\%$ men & age & disease & inclusion criteria \\
\hline & & & & & & $\begin{array}{l}\text { disseminated lung, breast, } \\
\text { prostate, head and neck, } \\
\text { oesophageal, colorectal, kidney, } \\
\text { bladder cancer or melanoma } \\
\text { skin cancer, and (d) had a recent } \\
\text { worst pain (past two weeks) } \\
\text { score of } 4 \text { or higher (on a scale } \\
\text { of 0-10) or pain in past two } \\
\text { weeks that interfered with } \\
\text { normal daily activities at least } \\
\text { moderately. }\end{array}$ \\
\hline $\begin{array}{l}\text { Van } \\
\text { Servellen, } \\
2005\end{array}$ & USA & 81 & $\sim 90 \%$ & $21-78$ & HIV & $\begin{array}{l}\text { Male or female, } 18 \text { yrs. plus, } \\
\text { problem with medic adherence } \\
\text { as charted in medical records, } \\
\text { time since diagnosis ( } 3 \text { months) } \\
\text { Receiving HAART for min } 3 \\
\text { months }\end{array}$ \\
\hline $\begin{array}{l}\text { Wilkie, } \\
2010\end{array}$ & USA & 151 & $\sim 70 \%$ & $\mid 62(10)$ & cancer (lung) & $\begin{array}{l}\text { (a) had a diagnosis of small cell } \\
\text { or non-small cell lung cancer; } \\
\text { (b) spoke and read English; and } \\
\text { (c) had pain related to the lung } \\
\text { cancer or to anticancer therapies } \\
\text { during the week prior to } \\
\text { enrolling }\end{array}$ \\
\hline
\end{tabular}


Aders, I., Smits, C., Brand, P., Dulmen, S. van. Does patient coaching make a difference in patient-physician communication during specialist consultations? A systematic review. Patient

Education and Counseling: 2016

Table 5. effects on communication.

\begin{tabular}{|c|c|c|c|c|}
\hline author, year & $\begin{array}{c}\text { primary and secondary } \\
\text { outcomes }\end{array}$ & $\begin{array}{c}\text { relevant } \\
\text { measurements }\end{array}$ & significant effects & $\begin{array}{l}\text { Meth. } \\
\text { quality }\end{array}$ \\
\hline Barlow, 2000, & $\begin{array}{l}\text { 1. Arthritis self-efficacy, } 2 \text {. } \\
\text { comprising use of cognitive } \\
\text { behavioral techniques for } \\
\text { managing arthritis, health status } \\
\text { and use of formal health } \\
\text { resources; }\end{array}$ & \begin{tabular}{|l} 
questionnaires \\
validated; 5 item scale \\
measuring \\
communication with \\
physician (self- \\
developed at Stanford \\
Arthritis Centre, \\
Lorig, 1996)
\end{tabular} & $\begin{array}{l}\text { Long term (4 and } 12 \\
\text { months) improved } \\
\text { communication with } \\
\text { physician. }\end{array}$ & high \\
\hline Bloom, 2008 & $\begin{array}{l}\text { 1. Breast cancer and treatment } \\
\text { knowledge, physical activity; } \\
\text { diet; (life style habits); patient } \\
\text { physician communication; } \\
\text { communication with family }\end{array}$ & \begin{tabular}{||l} 
questionnaires \\
validated and not- \\
validated; Breast \\
cancer problems scale
\end{tabular} & none & low \\
\hline $\begin{array}{l}\text { Boulware } \\
2013\end{array}$ & $\begin{array}{l}\text { participants' self-reported } \\
\text { achievement of at least } 1 \text { of } 5 \text { key } \\
\text { behaviors important in the } \\
\text { process of discussing and } \\
\text { pursuing living donor kidney } \\
\text { transplantation (ldkt), including: } \\
(1) \text { discussing ldkt with at least } \\
\text { one family member, (2) } \\
\text { discussing ldkt with their } \\
\text { physicians, (3) initiating the } \\
\text { clinical evaluation for potential } \\
\text { ldkt recipients, (4) completing } \\
\text { the clinical evaluation for } \\
\text { potential ldkt recipients, and (5) } \\
\text { identifying a } \\
\text { potential live kidney donor; } \\
\text { (interest in ldkt) } \\
\end{array}$ & \begin{tabular}{||l} 
\\
audiotape, interview \\
(telephone?), social \\
worker sessions, \\
questionnaires \\
validated and non- \\
validated, observation \\
by study staff; fidelity \\
of the intervention \\
was assessed
\end{tabular} & \begin{tabular}{||l} 
Long term $(6$ \\
months): more \\
discussion with \\
physician (TALK and \\
TALK social).
\end{tabular} & high \\
\hline Brown, 1999 & $\begin{array}{l}\text { 1. no. of questions asked during } \\
\text { oncology visit, } 2 \text {. anxiety; } \\
\text { satisfaction with consultation; } \\
\text { psychological adjustment to } \\
\text { cancer }\end{array}$ & \begin{tabular}{|l} 
audiotape, \\
questionnaires \\
validated; number of \\
questions, patient \\
satisfaction Roter; \\
observation by \\
researcher
\end{tabular} & none & low \\
\hline Davison, 1997 & $\begin{array}{l}\text { 1. active role in medical decision } \\
\text { making: preferred roles, assumed } \\
\text { roles, level of anxiety, levels of } \\
\text { depression, } 2 \text {. more active role in }\end{array}$ & \begin{tabular}{|l} 
audiotape: interviews \\
before and after (5-6 \\
weeks) initial \\
treatment consultation
\end{tabular} & $\begin{array}{l}\text { Immediate the } \\
\text { intervention group } \\
\text { assumed a more } \\
\text { active role in }\end{array}$ & high \\
\hline
\end{tabular}


Aders, I., Smits, C., Brand, P., Dulmen, S. van. Does patient coaching make a difference in patient-physician communication during specialist consultations? A systematic review. Patient

Education and Counseling: 2016

\begin{tabular}{|c|c|c|c|c|}
\hline author, year & $\begin{array}{c}\text { primary and secondary } \\
\text { outcomes }\end{array}$ & $\begin{array}{c}\text { relevant } \\
\text { measurements }\end{array}$ & significant effects & $\begin{array}{l}\text { Meth. } \\
\text { quality }\end{array}$ \\
\hline & communication with hcp & $\begin{array}{l}\text { using validated } \\
\text { questionnaire (CPS) }\end{array}$ & $\begin{array}{l}\text { treatment decision } \\
\text { making. Active role: } \\
\text { participate in } \\
\text { treatment decision } \\
\text { making. }\end{array}$ & \\
\hline $\begin{array}{l}\text { Greenfield, } \\
1985\end{array}$ & $\begin{array}{l}\text { 1. physician-patient interaction, } \\
\text { (behavior control, information } \\
\text { provision, emotion regulation); } \\
\text { preference for active } \\
\text { involvement in medical decision } \\
\text { making, 2. health status (general } \\
\text { health perception; number of } \\
\text { health problems; disability days; } \\
\text { level of health concern; and } \\
\text { physical and role limitations); } \\
\text { pain; involvement in medical } \\
\text { decision making; knowledge }\end{array}$ & \begin{tabular}{||l} 
\\
\\
audiotape, \\
questionnaires \\
validated; tapes, 8 \\
coding systems, \\
interviewing skills \\
measure; three blinded \\
coders
\end{tabular} & \begin{tabular}{|l} 
Immediate higher \\
levels of intensity of \\
conversation, \\
involvement (patient \\
utterances per minute, \\
controlling utterances \\
by patient, \\
assertiveness; ratio \\
patient- physician \\
utterances) \\
intermediate: \\
improved elicitation \\
of number of factual \\
statements from the \\
physician.
\end{tabular} & high \\
\hline $\begin{array}{l}\text { Greenfield, } \\
1988\end{array}$ & $\begin{array}{l}\text { 1. (Effect on physiological } \\
\text { health); HbA1; disease severity; } \\
\text { health related QoL; Change in } \\
\text { treatment regimen; } 2 \text {. Physician- } \\
\text { patient Interaction (involvement } \\
\text { in medical decision making; } \\
\text { number of conversational acts } \\
\text { per minute; number of questions } \\
\text { asked by patients; patient } \\
\text { satisfaction; number of } \\
\text { controlling behaviors by } \\
\text { patients); patient satisfaction and } \\
\text { knowledge of diabetes }\end{array}$ & \begin{tabular}{|l} 
audiotape, coded by \\
five blinded coders \\
(validated coding \\
scheme)
\end{tabular} & \begin{tabular}{|l} 
Immediate patient \\
activation in \\
conversational acts \\
per minute. Improved \\
“controlling” \\
behaviors (including \\
questions, \\
interruptions, and \\
directions); improved \\
ratio of patient to \\
physician \\
conversation (patient \\
participation), \\
obtaining \\
information, \\
improved controlling \\
verbal behavior.
\end{tabular} & high \\
\hline Kidd, 2004 & $\begin{array}{l}\text { 1. Number of questions asked in } \\
\text { consultation (audiotaped } \\
\text { recording), 2. self-efficacy in } \\
\text { asking questions, satisfaction } \\
\text { with the consultation, HbA1C }\end{array}$ & $\begin{array}{l}\text { audiotape: number of } \\
\text { questions asked; two } \\
\text { item questionnaire on } \\
\text { self-efficacy in } \\
\text { question asking (not } \\
\text { validated); }\end{array}$ & $\begin{array}{l}\text { intermediate self- } \\
\text { efficacy in question } \\
\text { asking, significantly } \\
\text { higher when } \\
\text { concerning a known } \\
\text { doctor, than unknown } \\
\text { doctor }\end{array}$ & low \\
\hline
\end{tabular}


Aders, I., Smits, C., Brand, P., Dulmen, S. van. Does patient coaching make a difference in patient-physician communication during specialist consultations? A systematic review. Patient

Education and Counseling: 2016

\begin{tabular}{|c|c|c|c|c|}
\hline author, year & $\begin{array}{c}\text { primary and secondary } \\
\text { outcomes }\end{array}$ & $\begin{array}{c}\text { relevant } \\
\text { measurements }\end{array}$ & significant effects & $\begin{array}{l}\text { Meth. } \\
\text { quality }\end{array}$ \\
\hline Kravitz, 2011 & $\begin{array}{l}\text { pain severity; pain impairment; } \\
\text { (MOS) functional status (SF-12); } \\
\text { pain misconceptions (SBQ); } \\
\text { communication self-efficacy } \\
\text { (PEPPI); pain control self- } \\
\text { efficacy (CPSE-scale) }\end{array}$ & $\begin{array}{l}\text { audiotape; self- } \\
\text { administered } \\
\text { questionnaires } \\
\text { (PEPPI-5) before and } \\
\text { immediately after, } \\
\text { validated; fidelity of } \\
\text { coaches was tested } \\
\end{array}$ & $\begin{array}{l}\text { Intermediate: TEC } \\
\text { group improved } \\
\text { communication self } \\
\text {-efficacy but the } \\
\text { groups already } \\
\text { differed significantly } \\
\text { at baseline. } \\
\end{array}$ & low \\
\hline Mishel, 2009 & $\begin{array}{l}\text { 1. Uncertainty management } \\
\text { (cancer knowledge; problem } \\
\text { solving; patient provider } \\
\text { communication); decisional } \\
\text { regret; medical communication } \\
\text { competence; } 2 \text {. use of } \\
\text { information resources; mood; } \\
\text { QoL }\end{array}$ & $\begin{array}{l}\text { audiotape (+ coded); } \\
\text { questionnaires } \\
\text { validated, Medical } \\
\text { communication } \\
\text { competence scale, } \\
\text { patient provider } \\
\text { communication scale; } \\
\text { telephone calls were } \\
\text { audiotaped for fidelity }\end{array}$ & $\begin{array}{l}\text { Intermediate (directly } \\
\text { after diagnosis) } \\
\text { improvement in TD } \\
\text { and TS group vs } \\
\text { control patient } \\
\text { provider } \\
\text { communication; long } \\
\text { term (4 weeks): } \\
\text { patient-provider } \\
\text { communication (both } \\
\text { groups vs control), } \\
\text { increased sharing of } \\
\text { information (pat tells } \\
\text { doctor) both groups } \\
\text { vs control; } \\
\text { participation in } \\
\text { planning treatment; } \\
\text { (TS group vs control) } \\
\text { Long term (3 } \\
\text { months): increase } \\
\text { sharing of } \\
\text { information (both } \\
\text { groups vs control). }\end{array}$ & high \\
\hline Ory, 2013 & $\begin{array}{l}\text { Triple Aim Affordable care Act } \\
\text { (1. better health, } 2 \text {. better } \\
\text { healthcare, including } \\
\text { communication with Physician } \\
\text { Scale, } 3 \text {. better value) }\end{array}$ & $\begin{array}{l}\text { validated } \\
\text { questionnaires; Better } \\
\text { Healthcare: } \\
\text { communication with } \\
\text { physician (Lorig); } \\
\text { Baseline and at } 6 \text { and } \\
12 \text { months } \\
\end{array}$ & $\begin{array}{l}\text { Long term 0-6 } \\
\text { months: improved } \\
\text { communication with } \\
\text { physician } 0-12 \\
\text { months: improved } \\
\text { communication with } \\
\text { physician. }\end{array}$ & low \\
\hline Sepucha, 2000 & $\begin{array}{l}\text { quality of treatment decisions, } \\
\text { the satisfaction with the } \\
\text { consultation, and the amount of } \\
\text { agreement between } \\
\text { patients and physicians, number } \\
\text { of FU visits before treatment }\end{array}$ & $\begin{array}{l}\text { validated and non- } \\
\text { validated } \\
\text { questionnaires: } \\
\text { Decision Quality } \\
\text { Scale; for Physicians: } \\
\text { MD Decision Scale; } \\
\text { San Francisco } \\
\text { Satisfaction with }\end{array}$ & $\begin{array}{l}\text { Immediate After CR: } \\
\text { intervention group } \\
\text { increase in decision } \\
\text { quality (PDS); } \\
\text { intersubjective } \\
\text { agreement between } \\
\text { physician and patient. }\end{array}$ & low \\
\hline
\end{tabular}


Aders, I., Smits, C., Brand, P., Dulmen, S. van. Does patient coaching make a difference in patient-physician communication during specialist consultations? A systematic review. Patient

Education and Counseling: 2016

\begin{tabular}{|c|c|c|c|c|}
\hline author, year & $\begin{array}{c}\text { primary and secondary } \\
\text { outcomes }\end{array}$ & $\begin{array}{c}\text { relevant } \\
\text { measurements }\end{array}$ & significant effects & $\begin{array}{l}\text { Meth. } \\
\text { quality }\end{array}$ \\
\hline & & $\begin{array}{l}\text { Consultation Scale } \\
\text { (SWC); in control } \\
\text { group: observation by } \\
\text { researcher; }\end{array}$ & & \\
\hline Sepucha, 2002 & $\begin{array}{l}\text { the effects of these interventions } \\
\text { on patients' reports of } \\
\text { communication barriers and on } \\
\text { patients' and } \\
\text { physicians' satisfaction with the } \\
\text { consultation }\end{array}$ & \begin{tabular}{||l} 
validated \\
questionnaires; \\
Community Breast \\
Health Project \\
(CBHP) scale of \\
communication \\
barriers; Satisfaction \\
with interview scale; \\
patient-Doctor \\
Interaction scale; \\
Physician satisfaction \\
scale
\end{tabular} & \begin{tabular}{|l} 
Immediate reduction \\
in communication \\
barriers (both groups, \\
not between groups).
\end{tabular} & low \\
\hline Smith, 2010 & $\begin{array}{l}\text { 1. Pain barriers; communication } \\
\text { skills; patient decision making; } 2 \text {. } \\
\text { patient outcomes; active } \\
\text { communication; pain associated } \\
\text { outcomes; barriers; facilitative } \\
\text { and receptiveness of physicians } \\
\text { influence on barriers and pain } \\
\text { associated outcomes }\end{array}$ & \begin{tabular}{|l} 
validated \\
questionnaires: \\
participatory data: \\
Perceived \\
Involvement with \\
Care Scale (M- \\
PICS = modified; \\
Barriers Questionnaire \\
(BQ); Patient \\
Satisfaction \\
Questionnaire \\
(PSQ18-adapted);
\end{tabular} & $\mid \begin{array}{l}\text { intermediate decline } \\
\text { over time of patient } \\
\text { barriers about pain in } \\
\text { intervention group, no } \\
\text { statistically } \\
\text { differences in the } \\
\text { other parameters }\end{array}$ & high \\
\hline Street, 2010 & $\begin{array}{l}\text { 1. active participation: } \\
\text { communication on pain: patients } \\
\text { questions; acts of assertiveness; } \\
\text { expressed concerns; } 2 \text {. quality of } \\
\text { physicians communication }\end{array}$ & \begin{tabular}{|l} 
audiotape, coders: \\
communication \\
measures: validated \\
coding system for \\
active participation of \\
patient (overall and \\
pain specific); \\
physicians \\
communication: \\
Kaplan's 3 items \\
participatory decision- \\
making scale \\
(adapted); overall \\
informativeness, 4 \\
items; pain specific \\
informativeness, 3 \\
items
\end{tabular} & \begin{tabular}{||l} 
Immediate pain \\
specific active \\
participation in TEC \\
group.
\end{tabular} & high \\
\hline
\end{tabular}


Aders, I., Smits, C., Brand, P., Dulmen, S. van. Does patient coaching make a difference in patient-physician communication during specialist consultations? A systematic review. Patient

Education and Counseling: 2016

\begin{tabular}{|c|c|c|c|c|}
\hline author, year & $\begin{array}{c}\text { primary and secondary } \\
\text { outcomes }\end{array}$ & $\begin{array}{c}\text { relevant } \\
\text { measurements }\end{array}$ & significant effects & $\begin{array}{l}\text { Meth. } \\
\text { quality }\end{array}$ \\
\hline $\begin{array}{l}\text { Van Servellen, } \\
2005\end{array}$ & $\begin{array}{l}\text { 1. Health literacy; patient- } \\
\text { provider communicational and } \\
\text { relation; adherence; perceived } \\
\text { quality of } \\
\text { relationship/communication with } \\
\text { medical staff; perceived quality } \\
\text { of relationship/communication } \\
\text { with their specific HIV treating } \\
\text { physician; } 2 \text {. health status } \\
\text { indicators } \\
\end{array}$ & \begin{tabular}{|l} 
Questionnaires \\
validated. Patient self- \\
report. Relation and \\
communication with \\
medical staff (doctors \\
and nurses, 7 items) \\
and treating physician \\
$(9$ items $)$.
\end{tabular} & $\begin{array}{l}\text { Long term (6 weeks } \\
\text { and } 6 \text { months) } \\
\text { relationships and } \\
\text { communications with } \\
\text { their treating } \\
\text { physicians and } \\
\text { medical staff. }\end{array}$ & high \\
\hline Wilkie, 2010 & $\begin{array}{l}\text { 1. amount of pain info } \\
\text { communicated to medical team } \\
\text { (recall of pain elements after one } \\
\text { week) elements: pattern, area, } \\
\text { intensity, nature; } 2 \text {. pain } \\
\text { prescriptions; pain relief; } \\
\text { anxiety; depression; } \\
\text { catastrophizing pain coping }\end{array}$ & $\begin{array}{l}\text { audiotapes of three } \\
\text { visits (baseline, } 2 \text { and } \\
4 \text { weeks) using } \\
\text { Audiotape Scoring } \\
\text { Tool (developed for } \\
\text { this study); }\end{array}$ & \begin{tabular}{|l||} 
Long term (4 weeks) \\
coached patients \\
communicated more \\
about pain, solicited \\
or unsolicited, and the \\
mean number of pain \\
parameters discussed \\
by patients increased.
\end{tabular} & hig \\
\hline
\end{tabular}

APPENDIX A. SEARCH STRATEGY PUBMED

\begin{tabular}{|c|}
\hline November 2015 , filters adult $(19+)$ and abstract available. \\
\hline (“interventions”[All Fields] OR “intervention”[All Fields] OR “coaching”[All Fields]) AND \\
\hline 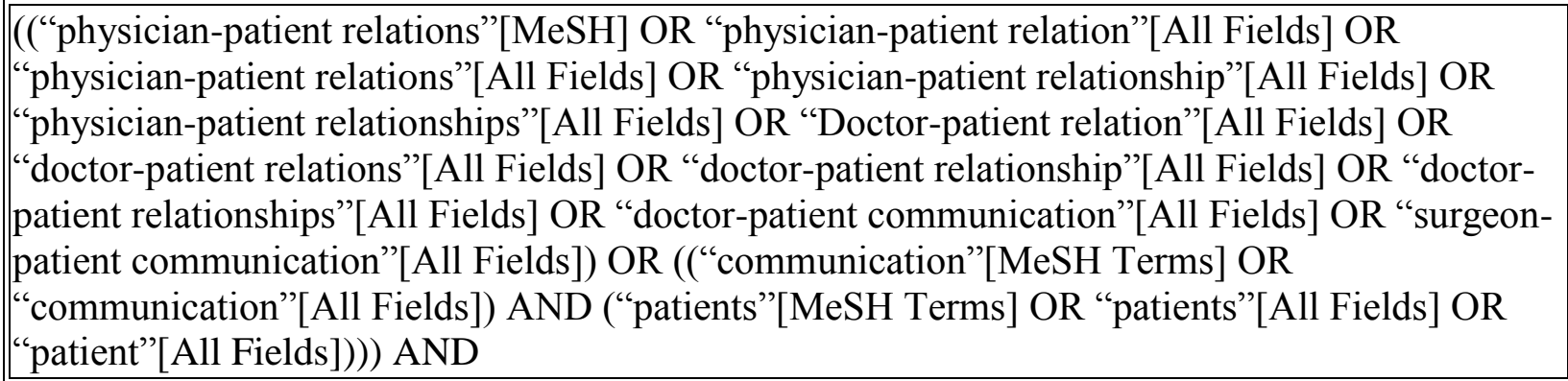 \\
\hline 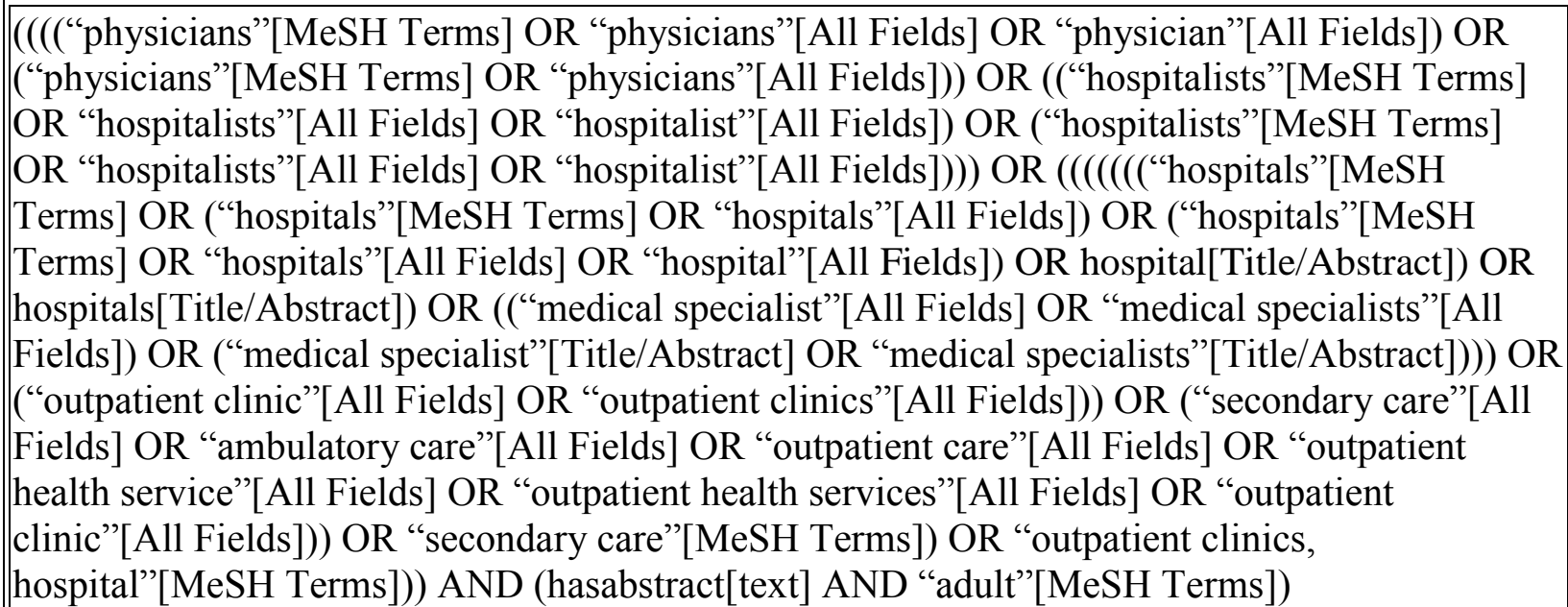 \\
\hline
\end{tabular}


Aders, I., Smits, C., Brand, P., Dulmen, S. van. Does patient coaching make a difference in patient-physician communication during specialist consultations? A systematic review. Patient Education and Counseling: 2016

APPENDIX B. COCHRANE ASSESSMENT OF METHODOLOGICAL QUALITY

\section{Assessment of methodological quality (RCT or quasi RCT): yes, no, unclear}

1) Was the method of randomisation adequate?

2) Was the treatment allocation concealed?

3) Were the groups similar at baseline regarding the most important prognostic indicators?

4) Was the patient blinded to the intervention?

5) Was the care provider blinded to the intervention?

6) Was the outcome assessor blinded to the intervention?

7) Were co-interventions avoided or similar?

8) Was the compliance acceptable in all groups?

9) Was the dropout rate described and acceptable?

10) Was the timing of the outcome assessment in all groups similar?

11) Did the analysis include an intention-to-treat analysis? 